\title{
Microrna in Human Gliomas
}

\author{
Alfredo Conti, Lucia Merlo, Domenico La Torre \\ and M'Hammed Aguennouz \\ Department of Neuroscience, University of Messina \\ Italy
}

\section{Introduction}

Glioblastoma multiforme (GBM) is the most common primitive malignant brain tumor. The GBM rapidly proliferates, invades and destroys surrounding brain tissues being nearly universally fatal in few months. Actual treatment options include surgery, radiotherapy, and chemotherapy using temozolomide (Stupp et al., 2005). As soon as the disease recurs, repeated surgery or administration of modified chemotherapy schemes give small chances of tumor growth control. Even with the most sophisticated treatments, the median overall survival for patients with GBM is actually estimated in approximately 15 months from diagnosis (Stupp et al., 2005).

Within the last few years, a more detailed knowledge of the genetic and molecular patterns of this cancer has led to laboratory's attempts in developing more targeted and effective therapies aiming to positively reverse its high mortality. While many important genetic features of GBM have been known for years or even decades through traditional methods, incremental technologies have allowed dramatic advances. New frontiers have been explored: the relatively recent discovery of microRNAs (miRNAs) has opened up a major new front in the war against GBM and other human tumors. A growing body of work is demonstrating key roles for them in GBM (Chan et al., 2005; Ciafre et al., 2005; Gillies \& Lorimer, 2007; Godlewski et al., 2008; Kefas et al., 2008; Kefas et al., 2009; Li et al., 2009; Silber et al., 2008; Würdinger et al., 2008).

Noteworthy is the cancer genome atlas (TCGA), a joint comprehensive and coordinated effort of the National Cancer Institute (NCI) and the National Human Genome Research Institute (NHGRI), funded by the National Institutes of Health (NIH) in 2006 to thoroughly initially profile three cancer types systematically assessing the molecular basis and the entire spectrum of genomic changes involved in human tumors through the application of innovative genome analysis technologies, including large-scale genome sequencing (http://cancergenome.nih.gov). After the success of the pilot project, TCGA is now expanding its efforts to more than 20 different human tumors in order to yield accessible data set that will improve diagnosis, treatment, prognosis, and even prevention. TCGA has also included studies on miRNA expression with microarrays, copy number analysis with array comparative genomic hybridization (CGH), and sequencing of over 600 genes of banked high-quality tumor specimens.

We here reviewed current literature on the role of miRNAs in GBM emphasizing the potential implications of these molecules as biomarkers and targets for therapy. 


\section{Biogenesis and functions of microRNAs}

The discovery of miRNAs dates back to 1993 when Lee et al. described a small RNA, lineage-deficient-4 (lin-4), with antisense complementarity to lin-14 involved in the regulation of developmental timing in Caenorhabditis elegans (Lee et al., 1993). At that time most investigators considered this small RNA as an oddity in worm genetics, but hundreds of these miRNAs were soon discovered in C. elegans and other animals by different laboratories (Lee \& Ambros, 2001; Pasquinelli et al., 2000).

miRNAs consist of 18 to 25 nucleotides and represent a class of endogenous ribo-regulators that modulate gene expression via the RNA interference (RNAi) pathway. RNAi is a posttranscriptional silencing mechanism, present in most eukaryotic organisms, in which exposure to double-stranded RNA induces the sequence specific degradation of homologous messenger RNAs (mRNA). miRNAs act by base-pairing with their target mRNAs through perfect or nearly perfect complementarity particularly at the $3^{\prime}$ untranslated regions (UTRs) of the target mRNAs (Lai, 2002; Robins \& Press, 2005) leading to their translational repression and/or direct cleavage (Meltzer, 2005).

To understand the mechanism of miRNA-mediated silencing, the basic steps of their biogenesis have to be summarized (Fig. 1). miRNAs originate from long primary miRNAs (pri-miRNAs) that are transcribed in the nucleus by the RNA polymerase II complex. miRNAs are then processed by a complex of the RNase III enzyme DROSHA and a doublestranded RNA binding domain possessing the protein DGCR8 (DiGeorge syndrome critical region gene 8), to 60-70 nucleotides precursor miRNA (pre-miRNA) intermediates. These hairpin-shaped pre-miRNAs are transported to the cytoplasm by Exportin-5 (Exp5) (a member of the Ran transport receptor family). Once in the cytoplasm, they are cleaved by DICER to generate 20 to 22 nucleotide duplexes bearing two nucleotide single-stranded 3' extensions. Finally, the miRNA: miRNA* duplex is unwound into a mature miRNA and miRNA* by a helicase. Single strand miRNA is incorporated into a ribonucleoprotein effector complex, known as the RNA-induced silencing complex (RISC), whereas miRNA* is degraded. RISC identifies target messages based on complementarities between the "guide" miRNA and the mRNA and results in either endonucleolytic cleavage of targeted mRNA or translational repression.

There are estimates, in part based on computational methods, that mammalian genomes encode up to 1,000 unique miRNAs (http://www.microrna.org/microrna/home.do), which are predicted to regulate the expression of as much as $60 \%$ of gene (Friedmann et al., 2009). Though more than 600 miRNAs have been identified in humans, much remains to be understood about their precise cellular function and role in the development of diseases. miRNAs are implicated in the control of many fundamental cellular and biological processes such as the developmental timing, stem cell division, and apoptosis (Brennecke et al., 2003; Chen et al., 2004; Cuellar \& McManus 2005; Harfe et al., 2005; Lim et al., 2005; Poy et al., 2004; Wilfred et al., 2007). Therefore changes in their expression may play a role in the development of diseases and cancer.

Calin and Croce first established a connection between microRNAs and cancer by showing that miR-15 and miR-16 are located on chromosome 13q14, a region deleted in more than half of B-cell chronic lymphocytic leukemia (CLL) (Calin \& Croce, 2006). Cimmino et al. then demonstrated that expression of miR-15a and miR-16-1was inversely correlated with Bcl-2 expression in CLL and that both miRNAs negatively regulated Bcl-2 at a posttranscriptional level, so explaining the exact role of those miRNAs in CLL. Furthermore, Bcl-2 repression by these miRNAs induced apoptosis in a leukemic cell line model (Cimmino et al., 2005). 


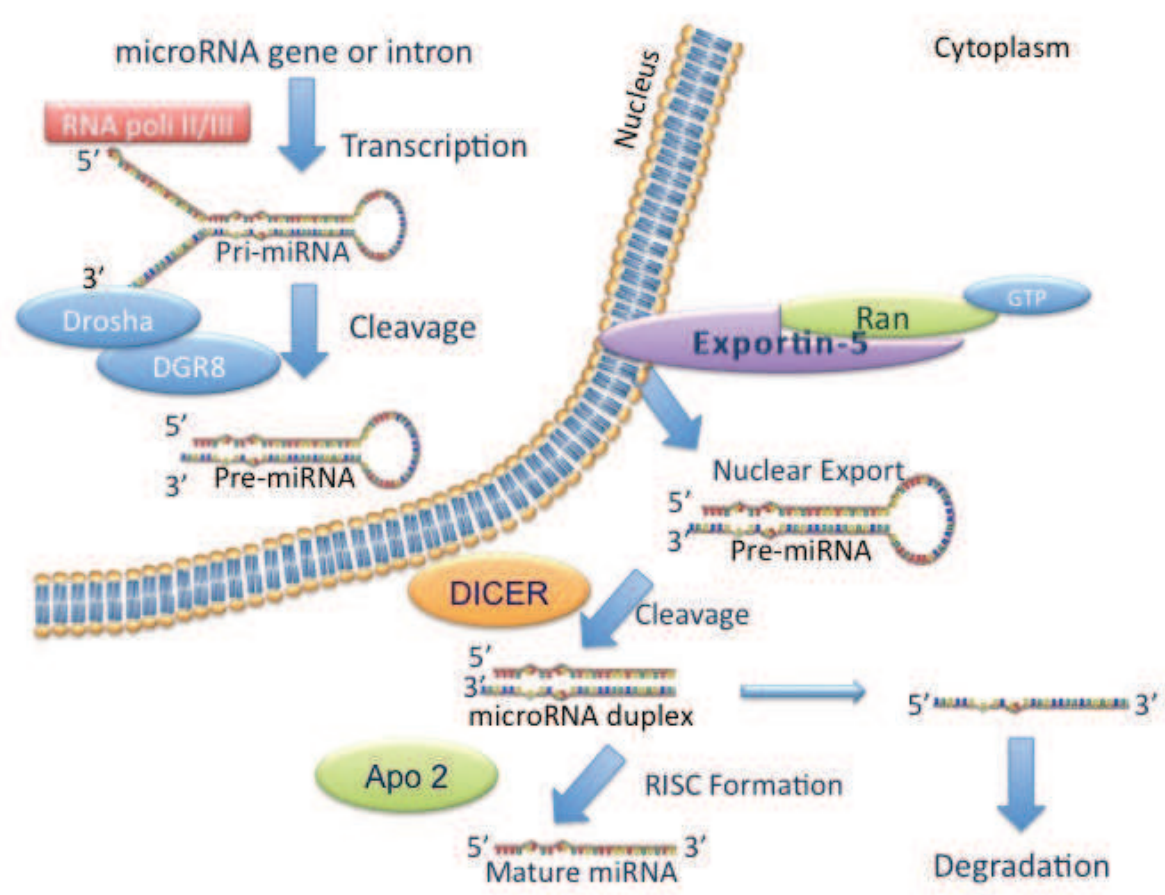

Fig. 1. Schematic representation of biogenesis of microRNA

\section{MicroRNAs in brain cancer}

Molecular-genetic, array-based gene profiling analysis of GBM, and gain- or loss-of-function study showed that specific deregulations in both mRNA and miRNAs are strongly associated with glioma development and progression (Juric et al., 2007; Kumar et al., 2007; Louis, 2006; Lukiw et al., 2009; Novakova et al., 2009; Pang et al., 2009; Tso et al., 2006; Zeng, 2009). It's possible to identify different subsets of miRNAs according to their main function into the development of GBM.

\subsection{Oncogenes}

The first oncomiR demonstrated as strongly overexpressed in GBM was miR-21 (Chan et al., 2005; Krichevsky et al., 2003) and it still remains the best characterized. miR-21 acts as oncogene in cultured GBM cells; moreover, it was found to be up-regulated yet in low-grade tumors (Conti et al., 2009). Its relevant targets appear to include tumor-suppressive genes (Frankel et al., 2008; Gabriely et al., 2008; Meng et al., 2007; Zhu et al., 2008). In fact, it has been demonstrated that inhibiting miR-21 by complementary antisense oligonucleotides in glioma cell lines decreases tumor cell viability inducing apoptosis both in vitro and in vivo settings (Chan et al., 2005, Corsten et al., 2007, Zhou et al., 2010). Recent researches showed 
how an overexpression of mir-21 could protect cultured human cells of GBM from temozolomide and taxol-induced apoptosis, suggesting a role in resistance to chemotherapeutic treatments (Ren et al., 2010; Shi et al., 2010). Even though an antiapoptotic role is likely for miR-21 in gliomas, other mechanisms are possible, because in Hela cells its down-regulation determines, instead, an increase in cell proliferation without affecting apoptosis. Meng et al. demonstrated that knock-down of miR-21 may render cholangiocarcinoma cells sensitive to gemcitabine whereas transfection of non-malignant cholangiocytes with the precursor of miR-21 renders them more resistant to this drug (Meng et al., 2007). This may be the result of downregulation of PTEN, the phosphatase that antagonizes the growth-promoting activity of the PI-3 kinase-Akt signaling pathway. It is noteworthy that PTEN was originally cloned as a oncosuppressor for brain tumors with point mutations occurring in $25 \%$ of cases. Further work by Frankel et al. on breast cancer cells (Frankel et al., 2008) and by Asangani et al. (Asangani et al., 2008) on colon cancer cells found that miR-21 overexpression leads to PDCD4 (programmed cell death 4) reduction, by direct interaction with its $3^{\prime}$ UTR, and that anti-miR-21 treatment is followed by an increase in endogenous PDCD4 protein levels. PDCD4 is a tumor suppressor known to be upregulated during apoptosis and reduced in different tumors, and evidence demonstrates that miR-21 overexpression effects are at least in part due to PDCD4 down-regulation. Although this target has not been proven in brain tumors, it is possible that it may be relevant also in these tumor types, as a recent study demonstrated that most of the glioma samples analyzed lacked PDCD4 protein expression whereas adjacent normal glial tissues expressed high levels of it. An additional molecular mechanism, proving the oncogenic properties of miR-21 in an in-vivo xenograft breast cancer model, consists in targeting of the tumor suppressor protein tropomyosin 1 (TPM1) at the translational level. Tropomyosin is able per se to reduce tumor cell proliferation and anchorage independence, therefore explaining the effects on tumor growth exerted by miR-21 (Zhu et al., 2007).

miR-221 and miR-222 are two oncogenic miRNA overexpressed in GBM which enhance cell proliferation and survival (Ciafre et al., 2005; Felicetti et al., 2008; Galardi et al., 2007; Lee et al., 2007) targeting cell cycle inhibitors.

Gillies and Lorimer defined a specific function of miRNA 221 and 222 in GBM, showing that they repress expression of the cell cycle regulatory protein p27Kip1 (Gillies \& Lorimer, 2007). The p27Kip1 gene is a member of the Cip/Kip family of cyclin-dependent kinase (CDK) inhibitors whose function is to negatively control cell cycle progression. The protein binds to CDK2 and cyclin E complexes to prevent cell cycle progression from G1 to S phase. p27Kip1 also acts as a tumor suppressor and its expression is often disrupted in human cancers. Analysis of the 3' UTR of p27Kip1 suggests that repression of this protein is a consequence of direct binding of miRNA 221 and 222 to sites in the 3' UTR. This mechanism was suggested contemporaneously and independently by le Sage et al. who demonstrated, using miRNA inhibitors, that some GBM cell lines require high activity of miR-221 and 222 to maintain low p27Kip1 levels and continuous proliferation, and that high levels of miR221 and 222 seem to correlate with low levels of p27Kip1 protein in GBM (le Sage et al., 2007). Gonzalez et al. have previously shown that inhibition of cdk4 activity enhances translation of p27Kip1, providing a link between these two cell-cycle regulators (Gonzalez et al., 2003). This effect was shown to be mediated by the 3' UTR of p27Kip1. The GBM cells used in that study were mutated at the INK4A/ARF locus and did not express the cdk4 
inhibitor p16Ink4a (Ishii et al., 1999). This suggested the possibility that loss of cdk4 inhibition through INK4a/ARF mutations causes an increase in miR-221 levels, and a consequent decrease in p27Kip1. p27Kip1 is a well-known tumor suppressor downregulated in many human tumors, and its expression in primary cancers is highly correlated with reduced patient survival.

Other oncomiR clusters affecting different targets that have been shown to be up-regulated in both GBM and other tumors are miR-10b (Ciafre et al., 2005; Ma et al., 2007; Silber et al., 2008) and the recently discovered miR-26a (Kim et al., 2010). miR-10b might play some role in the invasion of glioma cells by a positive regulation of RhoC (Sasayama et al., 2009) and urokinase-type plasminogen activator receptor (uPAR) and MMP-14 (Sun et al., 2011). miR26a is a direct regulator of PTEN expression and is frequently amplified at the DNA level in human glioma, most often in association with monoallelic loss of PTEN (Huse et al., 2009).

\subsection{Oncosuppressors}

miR-34a is a well-characterized molecule playing a role as tumor suppressor. It has been found to be an important downstream mediator of p53 (He et al., 2007; Luan et al., 2010; Sun et al., 2008). Recent reports suggested a role for miR-34a in GBM (Li et al., 2009) and in vitro studies described that its overexpression results in inhibition of neoplastic cell growth and apoptosis (Luan et al., 2010).

Other studies identified miR-124 and miR-137 as potential oncosuppressors (Silber et al., 2008). miR-124 seems to be the most down-regulated miRNA in GBM as compared with low-grade gliomas and healthy brain tissue. Down-regulation of miR-124 allows cell cycle progression and increases tumorigenic power by preventing neuronal differentiation (Godlewski et al., 2008; Silber et al., 2008). In vitro, the expression of miR-137 was found to be increased up to 12-fold (Silber et al., 2008). Moreover, transfection of miRNA-124 or miRNA-137 induced morphological changes and enhanced marker expression consistent with neuronal differentiation in mouse and human GBM-derived neural stem cells, also inducing G1 cell cycle arrest in GBM cells (Silber et al., 2008). These results led to hypothesize that targeted delivery of miRNA-124 and/or miRNA-137 to GBM tumor cells may be therapeutically employed.

Also miRNA-128 is significantly down-regulated in vivo and in GBM cell lines resulting in proliferation of undifferentiated cells. Moreover, in human glioma cell cultures the overexpression of miR-128 specifically blocks glioma self-renewal factors. This implicates that miR-128 may be used against the "stem cell-like" characteristics of glioma cells (Godlewski et al., 2008). In addition, the down-regulation of miRNA-128 was found to inversely correlate with tumor grade (Cui et al., 2010).

miRNA-181 may also play a role in glioma development. Shi et al. reported the downregulation of miR-181 and 181b in both human gliomas and glioma cell lines (Shi et al., 2008), confirming the data of Ciafre et al. (Ciafre et al., 2005). Those authors showed that transfection of those miRNAs triggered growth inhibition and apoptosis, and inhibited invasion. Furthermore, miR-181a expression turned out to be inversely correlated with tumor grading whereas miR-181b was uniformly downregulated in gliomas with different grades of malignancy.

miR-184 is another putative suppressor of glioma progression. The expression of miR-184 is down-regulated during progression from low-grade to GBM. Furthermore, its overexpression significantly decreases cell viability and proliferation of neoplastic cells, 
suggesting an anti-proliferative tumor-suppressive role of this miRNA, through a possible regulation of c-Myc (Würdinger et al., 2008). Interestingly, miR-184 is able to increase and reduce apoptotic activity and invasive growth in different subset of cultured cells (Malzkorn et al., 2010).

\subsection{Metabolism, angiogenesis, immunosuppression, treatment resistance}

MicroRNAs have been linked specifically with a number of key features affecting the viability of GBM cells including metabolism, angiogenesis, immunosuppression, radio- and chemoresistance.

Aberrant metabolism is increasingly recognized as critical issue in GBM biology. A report recently showed how miRNAs are involved in its regulation. miR-451, a miRNA with a role in cell proliferation and migration, is influenced by glucose levels and metabolic stress typically presented in GBM (Godlewski et al., 2010). It has been demonstrated that an increased expression of mirR-451 inhibits cell growth, inducing G0/G1 phase transition arrest, and predisposes to apoptosis. Furthermore, it diminishes the invasive capacity of GBM cells (Nan et al., 2010).

Angiogenesis plays a pivotal role in the progression of most solid tumors, and miR-296 is up-regulated in GBM-associated endothelial cells promoting tumor angiogenesis (Würdinger et al., 2008).

Immunosuppression is another trait allowing tumors to grow, and miRNAs have been shown to play a role here as well: miR-222 and miR-339 were found to promote GBM immune evasion by down-regulating the immunologic molecule ICAM-1 (Ueda et al., 2009). Treatment resistance is one of the principal challenges in GBM therapy, and early results of modern laboratory researches hint at a possible miRNAs involvement. In recent studies, a temozolomide-resistant GBM cell line was found to have several up-regulated miRNAs versus the parental line, including miR-21, miR-195, miR-455-3p, and miR-10a* (Shi et al., 2010; Ujifuku et al., 2010). Also during radiotherapy, miR-181a and miR-181b, usually down-regulated in GBM (Conti et al., 2009), may influence the sensitivity of this tumor to radiation (Slaby et al., 2010).

\subsection{Prognosis and grading}

A role for miRNAs as prognostic biomarkers as been suggested as well. Real-time PCR quantitative analysis revealed increased expression levels of miR-196 in GBM cells in comparison with both anaplastic astrocytomas and normal brain. Furthermore, this subset of neoplastic patients showed significantly poorer survival. The expression level of miR-196 was an independent predictor of overall survival (Guan et al., 2010).

miR-182 was markedly up-regulated both in glioma cell lines and in human tumor specimens. Quantitative PCR analysis showed that its expression was significantly upregulated in GBM compared with the adjacent healthy brain tissue. Furthermore, statistical analysis revealed a significant correlation between miR-182 expression and tumor grading placing miR-182 as independent prognostic indicator for disease progression and survival (Jiang et al., 2010).

Promising reliable biomarkers of GBM thoroughly studied so far are miR-21, miR-124 and miR-128.

As abovementioned, miR-21 acts as an oncogene whose inhibition in GBM cells induce apoptosis (Chan et al., 2005) and reduce tumor cells invasiveness (Gabriely et al., 2008). 
Recent studies also identified as miR-21 targets some tumor suppressors (Papagiannakopoulos \& Kosik, 2008) and inhibitors of matrix metalloproteinase (Gabriely et al., 2008). Moreover, its expression increases 5- to 100-fold during human glioma progression from lower grades to GBM (Chan et al., 2005), making miR-21 a consistent both diagnostic and prognostic marker.

miR-124 is downregulated in GBM. miR-124 has been identified as a suppressor of proteins that drive neural precursors toward non-neuronal fat (Makeyev et al., 2007). These data, together with the finding that one of the miR-124 targets is the oncogenic cyclin dependent kinase 6 (Pierson et al., 2008), support the role for miR-124 as a tumor suppressor and a potentially relevant biomarker in early diagnosis.

miR-128 is another neuron-specific miRNA involved in neural tissue differentiation. It acts as a tumor-suppressor gene and is downregulated in GBM (Ciafre et al., 2005; Godlewski et al., 2008). Recent studies have shown that it inhibits the cell cycle progression and GBM proliferation targeting a transcription factor (Zhang et al., 2009).

The study of epigenetics in GBM is another important frontier at a relatively early stage, and there are major discoveries yet to be made. Powerful input from this field has come during the last several years with the discovery of frequent methylation in GBM of the promoter of the MGMT gene (Gonzalez-Gomez et al., 2003). Found in about 30\% of GBMs, MGMT promoter methylation appears to sensitize this subset to the effects of temozolomide and confers improved prognosis (Hegi et al., 2005). A recent survey addresses miR-181 as a predictive marker for the responsiveness to the combination of radiotherapy and temozolomide, founding it downregulated in this cohort of patients (Slaby et al., 2010).

Despite the abovementioned evidence, it is quite clear that the use of a single miRNA as biomarker presently lacks of sufficient sensitivity and specificity, whereas the study of multiple miRNAs expression will possibly be used as a cluster to increase accuracy (Kong, et al., 2009).

\section{4. miRNAs: a future scenario}

There is a desperate need for developing innovative therapies for GBM. The clinical potential of delivering tumor-suppressive miRNAs or inhibitors of oncogenic miRNAs has been recently advocated (Brown et al., 2007; Edge et al., 2008; Gomez-Manzano \& Fueyo, 2010; $\mathrm{Wu}$ et al., 2009). The ability of individual miRNAs to target multiple genes/pathways and, at the same time, the capacity of multiple miRNAs in addressing the same $3^{\prime}$ UTR of a single gene, could be a major advantage, especially given the therapeutic necessity of simultaneously targeting multiple pathways in a multifaceted disease such as GBM. Furthermore, small-molecule drugs can have advantages like oral bioavailability and ability to penetrate the blood-brain barrier.

miRNAs are all expressed endogenously and are supposed to be safe for normal cells; nonetheless, their off-target effects would likely be much higher than other gene therapies targeted on a single gene/protein. Despite promising in vitro results, the use of miRNAs for the treatment of brain tumors poses great difficulties. A lot of interrogatives still remain under debate, but the main question rounds on how many molecules can be delivered and what kind of vehicle should be used to achieve therapeutic effects. So far, there are no studies to answer those questions.

More interestingly, with recent advances in detecting and quantifying miRNAs in tissue, serum, and cerebrospinal fluid it appears increasingly likely that they would be clinically 
useful as specific and reliable biomarkers patterns for brain tumors and other cancer diseases (De Smaele et al., 2010). Actually, miRNAs possess tissue specific expression in different regions of CNS (Bak et al., 2008; Cao et al., 2006; Trivedi \& Ramakrishna, 2009) and some of them have been found typically expressed in the human brain with low variability (Smirnova et al., 2005); moreover, they have also been demonstrated to be relevant for neural differentiation of embryonic stem cells (Smirnova et al., 2005) and in tumorigenesis. The feature conferring them this putative role in early diagnosis of malignant brain tumors is their scarce susceptibility to protease degradation. This aspect allows their detection not only from fresh specimens, but also from plasma and serum (Cortez \& Calin, 2009) and even after formalin fixation (Hasemeier et al., 2008). As for blood samples, miRNAs have been found in a more stable form, compared to mRNA, that is protected from endogenous RNase denaturation, either free (Mitchell et al., 2008) or enveloped in exosomes (Simpson et al., 2009). Glioblastoma derived exosomes founded in blood samples contain specific miRNAs (Skog et al., 2008). Hence the possibility to detect non-invasively miRNA in patients affected by GBM by the use of real time PCR has made them ideal candidates as biomarkers. Therefore, there is a possibility that they may be used as early diagnostic tools or markers of treatment response.

In conclusion, the uncovering of miRNAs has added a new level of complexity to our understanding in genetics of tumors. At the same time, it revealed a new category of therapeutic targets. There are huge amounts of data from researches that are still to be systematized, and new findings on miRNAs involved in GBM are expected from further analysis.

\section{References}

Asangani, I.A., Rasheed S.A., Nikolova, D.A., Leupold, J.H., Colburn, N.H., Post, S., \& Allgayer, H. (2008). MicroRNA-21 (miR-21) posttranscriptionally downregulates tumor suppressor Pdcd4 and stimulates invasion, intravasation and metastasis in colorectal cancer. Oncogene 27: 2128-2136.

Bak, M., Silahtaroglu, A., Moller, M., Christensen, M., Rath, M.F., Skryabin, B., Tommerup, N., \& Kauppinen, S. (2008). MicroRNA expression in the adult mouse central nervous system. RNA 14: 432-444.

Brennecke, J., Hipfner, D.R., Stark, A., Russell, R.B., \& Cohen, S.M. (2003). bantam encodes a developmentally regulated microRNA that controls cell proliferation and regulates the proapoptotic gene hid in Drosophila. Cell 113 (1): 25-36.

Brown, B.D., Gentner, B., Cantore, A., Colleoni, S., Amendola, M., Zingale, A., Baccarini, A., Lazzari, G., Galli, C., \& Naldini, L. (2007). Endogenous microRNA can be broadly exploited to regulate transgene expression according to tissue, lineage and differentiation state. Nat Biotechnol 25: 1457-1467.

Calin, G.A., \& Croce, C.M. (2006). MicroRNA signatures in human cancers. Nat Rev Cancer 6:857-866.

Cao, X., Yeo, G., Muotri, A.R., Kuwabara, T., \& Gage, F.H. (2006). Noncoding RNAs in the mammalian central nervous system. Annu Rev Neurosci 29, 77-103.

Chan, J.A., Krichevsky, A.M., \& Kosik, K.S. (2005). MicroRNA-21 is an antiapoptotic factor in human glioblastoma cells. Cancer Res 65(14): 6029-6033.

Chen, C.Z., Li, L., Lodish, H.F., \& Bartel, D.P. (2004). MicroRNAs modulate hematopoietic lineage differentiation. Science 303(5654): 83-6. 
Ciafre, S.A., Galardi, S., Mangiola, A., Ferracin, M., Liu, C.G., Sabatino, G., Negrini, M., Maira, G., Croce, C.M., \& Farace, M.G. (2005). Extensive modulation of a set of microRNAs in primary glioblastoma. Biochem Biophys Res Commun 334(4): 13511358.

Cimmino, A., Calin, G.A., Fabbri, M., Iorio, M.V., Ferracin, M., Shimizu, M., Wojcik, S.E., Aqeilan, R.I., Zupo, S., Dono, M., Rassenti, L., Alder, H., Volinia, S., Liu, C.G., Kipps, T.J., Negrini, M., \& Croce, C.M. (2005). miR-15 and miR-16 induce apoptosis by targeting BCL2. Proc Natl Acad Sci USA 102: 13944-13949.

Conti, A., Aguennouz, M., La Torre, D., Tomasello, C., Cardali, S., Angileri, F.F., Maio, F., Cama, A., Germanò, A., Vita, G., \& Tomasello, F. (2009). miR-21 and 221 upregulation and miR-181b downregulation in human grade II-IV astrocytic tumors. J Neurooncol 93(3): 325-332.

Corsten, M.F., Miranda, R., Kasmieh, R., Krichevsky, A.M., Weissleder, R., \& Shah, K. (2007). MicroRNA-21 knockdown disrupts glioma growth in vivo and displays synergistic cytotoxicity with neural precursor cell delivered S-TRAIL in human gliomas. Cancer Res 67: 8994-9000.

Cortez, M.A., \& Calin, G.A. (2009). MicroRNA identification in plasma and serum: a new tool to diagnose and monitor diseases. Expert Opin Biol Ther 9: 703-711.

Cuellar, T.L., \& McManus, M.T. (2005). MicroRNAs and endocrine biology. J Endocrinol 187(3): 327-332.

Cui, G.J. , Zhao, Y., Sethi, P., \& Li, Y.Y. (2010). Micro-RNA-128 (miRNA-128) downregulation in glioblastoma targets ARP5 (ANGPTL6), Bmi-1 and E2F-3a, key regulators of brain cell proliferation. J Neurooncol 98: 297-304.

De Smaele, E., Ferretti, E., \& Gulino, A. (2010). MicroRNAs as biomarkers for CNS cancer and other disorders. Brain Res 18;1338: 100-111.

Edge, R.E., Falls, T.J., Brown, C.W., Lichty, B.D., Atkins, H., \& Bell, J.C. (2008). A let-7 microRNA-sensitive vesicular stomatitis virus demonstrates tumor-specific replication. Mol Ther 16: 1437-1443.

Felicetti, F., Errico, M.C., Bottero, L., Segnalini, P., Stoppacciaro, A., Biffoni, M., Felli, N., Mattia, G., Petrini, M., Colombo, M.P., Peschle, C., \& Carè, A. (2008). The promyelocytic leukemia zinc finger-microRNA-221/-222 pathway controls melanoma progression through multiple oncogenic mechanisms. Cancer Res 68: 2745-2754.

Frankel, L.B., Christoffersen, N.R., Jacobsen, A., Lindow, M., Krogh, A., \& Lund, A.H. (2008). Programmed cell death 4 (PDCD4) is an important functional target of the microRNA miR-21 in breast cancer cells. J Biol Chem 283: 1026-1033.

Friedman, R.C., Farh, K.K., Burge, C.B., \& Bartel, D.P. (2009). Most mammalian mRNAs are conserved targets of microRNAs. Genome Res 19 (1): 92-105.

Gabriely, G., Würdinger, T., Kesari, S., Esau, C.C., Burchard, J., Linsley, P.S., \& Krichevsky, A.M. (2008). MiR-21 promotes glioma invasion by targeting MMP regulators. Mol Cell Biol 28: 5369-5380.

Galardi, S., Mercatelli, N., Giorda, E., Massalini, S., Frajese, G.V., Ciafrè, S.A., \& Farace, M.G. (2007). miR-221 and miR-222 expression affects the proliferation potential of human prostate carcinoma cell lines by targeting p27Kip1. J Biol Chem 282: 23716-23724.

Gillies, J.K., \& Lorimer, I.A. (2007). Regulation of p27Kip1 by miRNA 221/222 in glioblastoma. Cell Cycle 6(16): 2005-2009. 
Godlewski, J., Nowicki, M.O., Bronisz, A., Williams, S., Otsuki, A., Nuovo ,G., Raychaudhury, A., Newton, H.B., Chiocca, E.A., \& Lawler, S. (2008). Targeting of the Bmi-1 oncogene/stem cell renewal factor by microRNA-128 inhibits glioma proliferation and self-renewal. Cancer Res 68(22): 9125-9130.

Godlewski, J., Nowicki, M.O., Bronisz, A., Nuovo, G., Palatini, J., De Lay, M., Van Brocklyn, J., Ostrowski, M.C., Chiocca, E.A., \& Lawler, S.E. (2010). MicroRNA-451 regulates LKB1/AMPK signaling and allows adaptation to metabolic stress in glioma cells. Mol Cell 37: 620-632.

Gomez-Manzano, C., \& Fueyo, J. (2010). Oncolytic adenoviruses for the treatment of brain tumors. Curr Opin Mol Ther 12(5): 530-537.

Gonzalez, T., Seoane, M., Caamano, P., Vinuela, J., Dominguez, F., \& Zalvide, J. (2003). Inhibition of Cdk4 activity enhances translation of p27kip1 in quiescent $\mathrm{Rb}$ negative cells. J Biol Chem 278: 12688-12695.

Gonzalez-Gomez, P., Bello, M.J., Arjona, D., Lomas, J., Alonso, M.E., De Campos, J.M., Vaquero, J., Isla, A., Gutierrez, M., \& Rey, J.A. (2003). Promoter hypermethylation of multiple genes in astrocytic gliomas. Int J Oncol 22(3): 601-608.

Guan, Y., Mizoguchi, M., Yoshimoto, K., Hata, N., Shono, T., Suzuki, S.O., Araki, Y., Kuga, D., Nakamizo, A., Amano, T., Ma, X., Hayashi, K., \& Sasaki, T. (2010). MiRNA-196 is upregulated in glioblastoma but not in anaplastic astrocytoma and has prognostic significance. Clin Cancer Res 15;16(16): 4289-4297.

Harfe, B.D., McManus, M.T., Mansfield, J.H., Hornstein, E., \& Tabin, C.J. (2005). The RNaseIII enzyme Dicer is required for morphogenesis but not patterning of the vertebrate limb. Proc Natl Acad Sci USA 102(31): 10898-10903.

Hasemeier, B., Christgen, M., Kreipe, H., \& Lehmann, U. (2008). Reliable microRNA profiling in routinely processed formalin-fixed paraffin-embedded breast cancer specimens using fluorescence labelled bead technology. BMC Biotechnol 8: 90.

He, L., He, X., Lim, L.P., de Stanchina, E., Xuan, Z., Liang, Y., Xue, W., Zender, L., Magnus, J., Ridzon, D., Jackson, A.L., Linsley, P.S., Chen, C., Lowe, S.W., Cleary, M.A., \& Hannon, G.J. (2007). A microRNA component of the p53 tumour suppressor network. Nature 447: 1130-1134.

Hegi, M.E., Diserens, A.C., Gorlia, T., Hamou, M.F., de Tribolet, N., Weller, M., Kros, J.M., Hainfellner, J.A., Mason, W., Mariani, L., Bromberg, J.E., Hau, P., Mirimanoff, R.O., Cairncross, J.G., Janzer, R.C., \& Stupp, R. (2005). MGMT gene silencing and benefit from temozolomide in glioblastoma. N Engl J Med 352(10): 997-1003.

Huse, J.T., Brennan, C., Hambardzumyan, D., Wee, B., Pena, J., Rouhanifard, S.H., Sohn-Lee, C., le Sage, C., Agami, R., Tuschl, T., \& Holland, E.C. (2009). The PTEN-regulating microRNA miR-26a is amplified in high-grade glioma and facilitates gliomagenesis in vivo. Genes Dev 1;23(11): 1327-1337.

Ishii, N., Maier, D., Merlo, A., Tada, M., Sawamura, Y., Diserens, A.C., \& Van Meir, E.G. (1999). Frequent co-alterations of TP53, p16/ CDKN2A, p14ARF, PTEN tumor suppressor genes in human glioma cell lines. Brain Pathol 9: 469-479.

Jiang, L., Mao, P., Song, L., Wu, J., Huang, J., Lin, C., Yuan, J., Qu, L., Cheng, S.Y., \& Li, J. (2010). miR-182 as a prognostic marker for glioma progression and patient survival. Am J Pathol 177(1): 29-38. 
Juric, D., Bredel, C., Sikic, B.I., \& Bredel, M. (2007). Integrated high resolution genome-wide analysis of gene dosage and gene expression in human brain tumors. Methods Mol Biol 377: 187-202.

Kefas, B., Godlewski, J., Comeau, L., Li, Y., Abounader, R., Hawkinson, M., Lee, J., Fine, H., Chiocca, E.A., Lawler, S., \& Purow, B. (2008). microRNA-7 inhibits the epidermal growth factor receptor and the Akt pathway and is down-regulated in glioblastoma. Cancer Res 68(10): 3566-3572.

Kefas, B., Comeau, L., Floyd, D.H., Seleverstov, O., Godlewski, J., Schmittgen, T., Jiang, J., diPierro, C.G., Li, Y., Chiocca, E.A., Lee, J., Fine, H., Abounader, R., Lawler, S., \& Purow, B. (2009). The neuronal microRNA miR-326 acts in a feedback loop with notch and has therapeutic potential against brain tumors. J Neurosci 29(48): 1516115168.

Kim, H., Huang, W., Jiang, X., Pennicooke, B., Park , P.J., \& Johnson M.D. (2010). Integrative genome analysis reveals an oncomir/oncogene cluster regulating glioblastoma survivorship. Proc Natl Acad Sci USA 107: 2183-2188.

Kong, W., Zhao, J.J., He, L., \& Cheng, J.Q. (2009). Strategies for profiling microRNA expression. J Cell Physiol 218: 22-25.

Krichevsky, A.M., King, K.S., Donahue, C.P., Khrapko, K., \& Kosik, K.S. (2003). A microRNA array reveals extensive regulation of microRNAs during brain development. RNA 9: 1274-1281.

Kumar, M.S., Lu, J., Mercer, K.L., Golub, T.R., \& Jacks, T. (2007). Impaired microRNA processing enhances cellular transformation and tumorigenesis. Nat Genet 39: 673677.

Lai, E.C. (2002). Micro RNAs are complementary to 30 UTR sequence motifs that mediate negative post-transcriptional regulation. Nat Genet 30: 363-364.

le Sage, C., Nagel, R., Egan, D.A., Schrier, M., Mesman, E., Mangiola, A., Anile, C., Maira, G., Mercatelli, N., Ciafre, S.A., Farace, M.G., \& Agami, R. (2007). Regulation of the p27(Kip1) tumor suppressor by miR-221 and miR-222 promotes cancer cell proliferation. EMBO J 26: 3699-3708.

Lee, R.C., Feinbaum, R.L., \& Ambros, V. (1993). The C. elegans heterochronic gene lin-4 encodes small RNAs with antisense complementarity to lin-14. Cell 75 (5): 843-854.

Lee, R.C., \& Ambros, V. (2001). An extensive class of small RNAs in Caenorhabditis elegans. Science 294: 862-864.

Lee, E.J., Gusev, Y., Jiang, J., Nuovo, G.J., Lerner, M.R., Frankel, W.L., Morgan, D.L., Postier, R.G., Brackett, D.J., \& Schmittgen T.D. (2007). Expression profiling identifies microRNA signature in pancreatic cancer. Int J Cancer 120: 1046-1054.

Li, Y., Guessous, F., Zhang, Y., Dipierro, C., Kefas, B., Johnson, E., Marcinkiewicz, L., Jiang, J., Yang, Y., Schmittgen, T.D., Lopes, B., Schiff, D., Purow, B., \& Abounader, R. (2009). MicroRNA-34a inhibits glioblastoma growth by targeting multiple oncogenes. Cancer Res 69(19): 7569-7576.

Lim, L.P., Lau, N.C., Garrett-Engele, P., Grimson, A., Schelter, J.M., Castle, J., Bartel, D.P., Linsley, P.S., \& Johnson, J.M. (2005). Microarray analysis shows that some microRNAs downregulate large numbers of target mRNAs. Nature 433(7027): 769773.

Louis, D.N. (2006). Molecular pathology of malignant gliomas. Annu Rev Pathol 1: 97-117. 
Luan, S., Sun, L., \& Huang, F. (2010). MicroRNA-34a: a novel tumor suppressor in p53mutant glioma cell line U251. Arch Med Res 41(2): 67-74.

Lukiw, W.J., Cui, J.G., Li, Y.Y., \& Culicchia, F. (2009). Up-regulation of micro-RNA221(miRNA-221; chr Xp11.3) and caspase-3 accompanies down-regulation of the survivin-1 homolog BIRC1 (NAIP) in glioblastoma multiforme (GBM). J Neurooncol 91: 27-32.

Ma, L., Teruya-Feldstein, J., \& Weinberg, R.A. (2007). Tumour invasion and metastasis initiated by microRNA-10b in breast cancer. Nature 449: 682-688.

Makeyev, E.V., Zhang, J., Carrasco, M.A., \& Maniatis, T. (2007). The MicroRNA miR-124 promotes neuronal differentiation by triggering brain-specific alternative premRNA splicing. Mol.Cell 27: 435-448.

Malzkorn, B., Wolter, M., Liesenberg, F., Grzendowski, M., Stühler, K., Meyer, H.E., \& Reifenberger, G. (2010). Identification and functional characterization of microRNAs involved in the malignant progression of gliomas. Brain Pathology 20: 539-550.

Meltzer, P.S. (2005). Cancer genomics: small RNAs with big impacts. Nature 435: 745-746.

Meng, F., Henson, R., Wehbe-Janek, H., Ghoshal, K., Jacob, S.T., \& Patel, T. (2007). MicroRNA-21 regulates expression of the PTEN tumor suppressor gene in human hepatocellular cancer. Gastroenterology 133: 647-658.

microRNA.org-Targets and Expression. Date of access: November, 30, 2010, Available from http://www.microrna.org/microrna/home.do.

Mitchell, P.S., Parkin, R.K., Kroh, E.M., Fritz, B.R., Wyman, S.K., Pogosova-Agadjanyan, E.L., Peterson, A., Noteboom, J., O'Briant, K.C., Allen, A., Lin, D.W., Urban, N., Drescher, C.W., Knudsen, B.S., Stirewalt, D.L., Gentleman, R., Vessella, R.L., Nelson, P.S., Martin, D.B., \& Tewari, M. (2008). Circulating microRNAs as stable blood-based markers for cancer detection. Proc Natl Acad Sci USA 105: 10513-10518.

Nan, Y., Han, L., Zhang, A., Wang, G., Jia, Z., Yang, Y., Yue, X., Pu, P., Zhong, Y., \& Kang, C. (2010). MiRNA-451 plays a role as tumor suppressor in human glioma cells. Brain Res 4;1359: 14-21.

Novakova, J., Slaby, O., Vyzula, R., \& Michalek, J. (2009). Micro RNA involvement in glioblastoma pathogenesis. Biochem Biophys Res Commun 386: 1-5.

Pang, J.C.S., Kwok, W.K., Chen, Z., \& Ng, H.K. (2009). Oncogenic role of microRNAs in brain tumors. Acta Neuropathol 117: 599-611.

Papagiannakopoulos, T., \& Kosik, K.S. (2008). MicroRNAs: regulators of oncogenesis and stemness. BMC Med 6, 15.

Pasquinelli, A.E., Reinhart, B.J., Slack, F., Martindale, M.Q., Kuroda, M.I., Maller, B., Hayward, D.C., Ball, E.E., Degnan, B., Müller, P., Spring, J., Srinivasan, A., Fishman, M., Finnerty, J., Corbo, J., Levine, M., Leahy, P., Davidson, E., \& Ruvkun, G. (2000). Conservation of the sequence and temporal expression of let-7 heterochronic regulatory RNA. Nature 408(6808): 86-89.

Pierson, J., Hostager, B., Fan, R., \& Vibhakar, R. (2008). Regulation of cyclin dependent kinase 6 by microRNA 124 in medulloblastoma. J Neurooncol 90, 1-7.

Poy, M.N., Eliasson, L., Krutzfeldt, J., Kuwajima, S., Ma, X., Macdonald, P.E., Pfeffer, S., Tuschl, T., Rajewsky, N., Rorsman, P., \& Stoffel, M. (2004). A pancreatic isletspecific microRNA regulates insulin secretion. Nature 432(7014): 226-230. 
Ren, Y., Zhou, X., Mei, M., Yuan, X.B., Han, L., Wang, G.X., Jia, Z.F., Xu, P., Pu, P.Y., \& Kang, C.S. (2010). MicroRNA-21 inhibitor sensitizes human glioblastoma cells U251 (PTEN-mutant) and LN229 (PTEN-wild type) to taxol. BMC Cancer 31; 10:27.

Robins, H., \& Press, W.H. (2005). Human microRNAs target a functionally distinct population of genes with AT-rich 30 UTRs. Proc Natl Acad Sci USA 102:15557-15562.

Sasayama, T., Nishihara, M., Kondoh, T., Hosoda, K., \& Kohmura, E. (2009). MicroRNA-10b is overexpressed in malignant glioma and associated with tumor invasive factors, uPAR and RhoC. Int J Cancer 15;125(6): 1407-1413.

Shi, L., Cheng, Z., Zhang, J., Li, R., Zhao, P., Fu, Z., \& You, Y. (2008). hsamir- 181a and hsamir-181b function as tumor suppressors in human glioma cells. Brain Res 1236: 185193.

Shi, L., Chen, J., Yang, J., Pan, T., Zhang, S., \& Wang, Z. (2010). MiR-21 protected human glioblastoma U87MG cells from chemotherapeutic drug temozolomide induced apoptosis by decreasing Bax/Bcl-2 ratio and caspase-3 activity. Brain Res 17;1352: 255-264.

Silber, J., Lim, D.A., Petritsch, C., Persson, A.I., Maunakea, A.K., Yu, M., Vandenberg, S.R., Ginzinger, D.G., James, C.D., Costello, J.F., Bergers, G., Weiss, W.A., AlvarezBuylla, A., \& Hodgson, J.G. (2008). miR-124 and miR-137 inhibit proliferation of glioblastoma multiforme cells and induce differentiation of brain tumor stem cells. BMC Med 6: 14.

Simpson, R.J., Lim, J.W., Moritz, R.L., \& Mathivanan, S. (2009). Exosomes: proteomic insights and diagnostic potential. Expert Rev Proteomics 6: 267-283.

Skog, J., Würdinger, T., van Rijn, S., Meijer, D.H., Gainche, L., Sena-Esteves, M., Curry, W.T. Jr, Carter, B.S., Krichevsky, A.M., \& Breakefield, X.O. (2008). Glioblastoma microvesicles transport RNA and proteins that promote tumour growth and provide diagnostic biomarkers. Nat Cell Biol 10: 1470-1476.

Slaby, O., Lakomy, R., Fadrus, P., Hrstka, R., Kren, L., Lzicarova, E., Smrcka, M., Svoboda, M., Dolezalova, H., Novakova, J., Valik, D., Vyzula, R., \& Michalek, J. (2010). MicroRNA-181 family predicts response to concomitant chemoradiotherapy with temozolomide in glioblastoma patients. Neoplasma 57: 264-269.

Smirnova, L., Grafe, A., Seiler, A., Schumacher, S., Nitsch, R., \& Wulczyn, F.G. (2005). Regulation of miRNA expression during neural cell specification. Eur J NeuroSci 21: 1469-1477.

Stupp, R., Mason, W.P., van den Bent, M.J., Weller, M., Fisher, B., Taphoorn, M.J., Belanger, K., Brandes, A.A., Marosi, C., Bogdahn, U., Curschmann, J., Janzer, R.C., Ludwin, S.K., Gorlia, T., Allgeier, A., Lacombe, D., Cairncross, J.G., Eisenhauer, E., \& Mirimanoff, R.O. (2005). Radiotherapy plus concomitant and adjuvant temozolomide for glioblastoma. N Engl J Med 352(10): 987-996.

Sun, F., Fu, H., Liu, Q., Tie, Y., Zhu, J., Xing, R., Sun, Z., \& Zheng, X. (2008). Downregulation of CCND1 and CDK6 by miR-34a induces cell cycle arrest. FEBS Lett 582: 15641568.

Sun, L., Yan, W., Wang, Y., Sun, G., Luo, H., Zhang, J., Wang, X., You, Y., Liu, N., Yang, Z. (2011). MicroRNA-10b induces glioma cell invasion by modulating MMP-14 and uPAR expression via HOXD10. Brain Res 15.

TCGA: The Cancer Genome Atlas. Date of access: November, 30, 2010, Available from: http://cancergenome.nih.gov. 
Trivedi, S., \& Ramakrishna, G. (2009). miRNA and neurons. Int J Neurosci 119: 1995-2016.

Tso, C.L., Freije, W.A., Day, A., Chen, Z., Merriman, B., \& Perlina, A. (2006). Distinct transcription profiles of primary and secondary glioblastoma subgroups. Cancer Res 66: 159-167.

Ueda, R., Kohanbash, G., Sasaki, K., Fujitaa, M., Zhua, X., Kastenhuberb, E.R., McDonaldb, H.A., Potterb, D.M., Hamiltonb, R.L., Lotzef, M.T., Khane, S.A., Sobolb, R.W., \& Okada, H. (2009). Dicer-regulated microRNAs 222 and 339 promote resistance of cancer cells to cytotoxic T-lymphocytes by down-regulation of ICAM-1. Proc Natl Acad Sci USA 106: 10746-10751.

Ujifuku, K., Mitsutake, N., Takakura, S., Matsuse, M., Saenko, V., Suzuki, K., Hayashi, K., Matsuo, T., Kamada, K., Nagata, I., \& Yamashita, S. (2010). miR-195, miR-455-3p and $\mathrm{miR}-10 \mathrm{a}\left(^{*}\right)$ are implicated in acquired temozolomide resistance in glioblastoma multiforme cells. Cancer Lett 296: 241-248.

Wilfred, B.R., Wang, W.X., \& Nelson, P.T. (2007). Energizing miRNA research: a review of the role of miRNAs in lipid metabolism, with a prediction that miR-103/107 regulates human metabolic pathways. Mol Genet Metab 91(3): 209-217.

Wu, C., Lin, J., Hong, M., Choudhury, Y., Balani, P., Leung, D., Dang, L.H., Zhao, Y., Zeng, J., \& Wang, S. (2009). Combinatorial control of suicide gene expression by tissuespecific promoter and microRNA regulation for cancer therapy. Mol Ther 17: 20582066.

Würdinger, T., Tannous, B.A., Saydam, O., Skog, J., Grau, S., Soutschek, J., Weissleder, R., Breakefield, X.O., \& Krichevsky, A.M. (2008). miR-296 regulates growth factor receptor overexpression in angiogenic endothelial cells. Cancer Cell 14(5): 382-393.

Zeng, Y. (2009). Regulation of the mammalian nervous system by micro-RNAs. Mol Pharmacol 75: 259-264.

Zhang, Y., Chao, T., Li, R., Liu, W., Chen, Y., Yan, X., Gong, Y., Yin, B., Liu, W., Qiang, B., Zhao, J., Yuan, J., \& Peng, X. (2009). MicroRNA-128 inhibits glioma cells proliferation by targeting transcription factor E2F3a. J Mol Med 87: 43-51.

Zhou, X., Zhang, J., Jia, Q., Ren, Y., Wang, Y., Shi, L., Liu, N., Wang, G., Pu, P., You, Y., \& Kang, C. (2010). Reduction of miR-21 induces glioma cell apoptosis via activating caspase 9 and 3. Oncol Rep 24(1): 195-201.

Zhu, S., Si, M.L., Wu, H., \& Mo, Y.Y. (2007). MicroRNA-21 targets the tumor suppressor gene tropomyosin 1 (TPM1). J Biol Chem 282: 14328-14336.

Zhu, S., Wu, H., Wu, F., Nie, D., Sheng, S., \& Mo, Y.Y. (2008). MicroRNA-21 targets tumor suppressor genes in invasion and metastasis. Cell Res 18: 350-359.

Aknowledgement: the study was financed by COFIN 2008 prot. 2008979M8K-001 by Italian Ministry of University and Research 


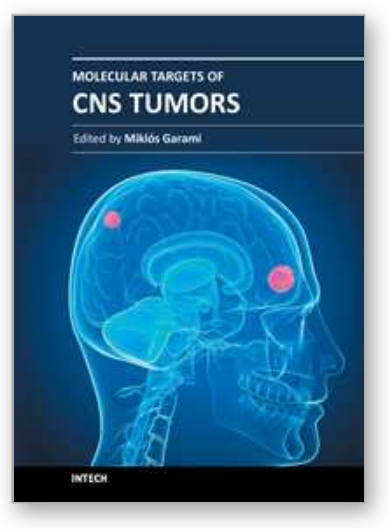

\author{
Molecular Targets of CNS Tumors \\ Edited by Dr. Miklos Garami
}

ISBN 978-953-307-736-9

Hard cover, 674 pages

Publisher InTech

Published online 22, September, 2011

Published in print edition September, 2011

Molecular Targets of CNS Tumors is a selected review of Central Nervous System (CNS) tumors with particular emphasis on signaling pathway of the most common CNS tumor types. To develop drugs which specifically attack the cancer cells requires an understanding of the distinct characteristics of those cells. Additional detailed information is provided on selected signal pathways in CNS tumors.

\title{
How to reference
}

In order to correctly reference this scholarly work, feel free to copy and paste the following:

Alfredo Conti, Lucia Merlo, Domenico La Torre and M'Hammed Aguennouz (2011). MicroRNA in Human Gliomas, Molecular Targets of CNS Tumors, Dr. Miklos Garami (Ed.), ISBN: 978-953-307-736-9, InTech, Available from: http://www.intechopen.com/books/molecular-targets-of-cns-tumors/microrna-in-human-gliomas

\section{INTECH}

open science | open minds

\section{InTech Europe}

University Campus STeP Ri

Slavka Krautzeka 83/A

51000 Rijeka, Croatia

Phone: +385 (51) 770447

Fax: +385 (51) 686166

www.intechopen.com

\section{InTech China}

Unit 405, Office Block, Hotel Equatorial Shanghai

No.65, Yan An Road (West), Shanghai, 200040, China

中国上海市延安西路65号上海国际贵都大饭店办公楼405单元

Phone: +86-21-62489820

Fax: $+86-21-62489821$ 
(C) 2011 The Author(s). Licensee IntechOpen. This chapter is distributed under the terms of the Creative Commons Attribution-NonCommercialShareAlike-3.0 License, which permits use, distribution and reproduction for non-commercial purposes, provided the original is properly cited and derivative works building on this content are distributed under the same license. 